\title{
Hõimlane verejõe tagant: Saami muinaslood tootempõhjapõdrast. V
}

\author{
$\underline{\text { Enn Ernits }}$
}

"Mäetaguste" käesolevas osas jätkub põhjapõdra lahkumislugude analüüs.

Kaheteistkümnes jutt (kokkuvõtet vt "Mäetagused", nr 6, lk 21 jj)

Asjaomases Turja variandis esineb erinevalt teistest lugudest kaks pahategu: ühe põhjustas eit enne põhjapõtrade pagemist, teise aga pärast seda. Esimest pahategu on kirjeldatud järgmiselt:

Eit hakkas riidlema, et siin ei toimita nõnda nagu tema pool kodus: magamise järel tuleb laste märg ase kuivatada, mitte aga vette visata. Elu veeres edasi. Meandashi naine kuulas ema sõna. Ta asetas märjad nahad ukse kohale päikese kätte kuivama, kuid unustaski need sinna.

Katkendis kajastub taotluslik paradoks: ühelt poolt oli keelatud asemenahkade kuivatamine päikese käes, teisalt aga tuli olla vanematele sõnakuulelik, sest elureeglite eiramine võib saada saatuslikuks.

Põhjapõdra pagemisega seonduvat kujutatakse niiviisi:

Päike veeres looja. Meandash jõudis koja sissekäigu juurde. Sinna aga olid asemed kuivama pandud; neist tuli kirbet haisu. Meandashile lõi hais ninna, ta tõmbas kõrvad lidusse, aevastas korra, kui ei suutnud inimeseks moonduda.

Meandash hü̈dis:

"Miks pandi asemed kuivama?" Ta jooksis metsa ja lippas tundrusse. Ka kõik lapsed, kõik meandash-paarrnid, tema lapsukesed, lippasid üksteise kannul talle järele.

Isegi kõige väiksem laps, kes oli ema süles ja imes rinda, võpatas ning sööstis põdravasikaks moondunult teistele järele.

Meandash-koab jäi üksi. Ta sööstis neile järele, tormas neile kannule ja kutsus pisikest põlvele istuma, kutsus teda koju:

"Tule ema juurde koju! Tule ema juurde, tule! Tule, emal on tissi. Tule ema juurde, tule ometi. Emal on soojad põlved ning tissid."

Meandash-paarrn aga hü̈dis vastu:

"Ma ei saa tagasi tulla, ema, ma ei saa! Mind kisub kaasa põhjapõtrade vabaduselust. Mind kisub ühes põhjapõtrade kutse. Mind vaimustab noorte sarvede tuhin! Lumetormiga mängimine pakub mulle lõbu! Sõrgade rudin on mu rõõm! Ma ei saa koju tulla, ema, ma ei saa koju tulla!"

Ema hü̈idis vastu:

"Alatusest hoia end eemale! Õnnelikule mine lähemale! Olgu su silmad pilukil ja su küljed noole trehvata! Ole tavalisele inimesele ( $\underline{* 23}$ ) oiduseks!"

Negatiivse sündmuse toimumisaeg on õhtu. Keelu eiramisega rikutakse tasakaal, Meandash ei suuda enam inimeseks moonduda ja põgeneb. Meandash-paarrni kaunisõnaline jutt näikse olevat vähemalt osaliselt V. Tsharnoluski looming (vrd ka XIV ja XV jutt). Ema hoiatus hoida silmi 
pilukil väljendab soovi kütti pilguga mitte kahjustada, sest Meandash võib inimese pimestada (sellest lähemalt sarja järgmises osas).

Väga sarnane on XV jutt, samuti sellega peaaegu identne XVII lugu. Teist korda abiellus põhjapõdra abikaasa inimesega, kuid elu ei kulgenud õnnetähe all. Põhjapõder õpetas endist naist unes:

Ükskord Meandash-koab magas ja nägi unes, et tema ette ilmus Meandash, tema endine mees. See lausus hellitlevi hääli:

"Armas naisuke, mul on sinust kahju. Mul on sinu elust väga kahju. Ma tean kõik. Ma ei suuda sinu piinu taluda. Ütle oma mehele, ütle talle, et ta mind pühapaigas maha laseks! Las ta tuleb koidu ajal ja tabab mind. Minu nahk võta aga endale ja sea oma asemele."

Hommikul tõusis Meandash-koab üles ning õpetas mehele, mida ette võtta.

Mees võttis kuulda. Ta läks pühapaika ja laskis põhjapõdra maha."

Siit selgub naha osa saami usundis - sellega kandus jahiõnn edasi kõigile saamidele. J. Sergejeva (1994: 169) osutab, et tapmismotiiv väljendab ohverdamisrituaali. Loost nähtub, et püha looma ei saanud tappa kus juhtub, vaid sakraalse objektiga sai kontakteeruda üksnes sakraalses kohas. Tähelepanuväärne on põhjapõdra poolt soovitatud mahalaskmisaeg, mis ühtib positiivselt märgistatud piirajaga.

Tapetud püha looma nahast ja teistest elunditest lähtuv vägi ulatus kaugemale. Tõenäoliselt kajastub saami jutus kogu maailmas levinud müüt surevast ja taassündivast ulukist. Püha looma tapmise rituaal on küttidel seotud usuga, et see ärkab uuesti ellu või sünnib taas. Saami usundis ei tohtinud luid minema

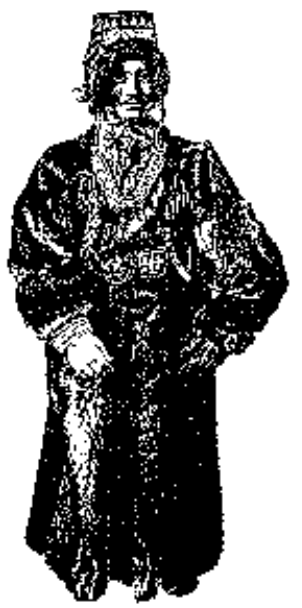
visata ega rikkuda, vaid pea koos sarvedega ja luud alles jäänud liigesesidemetega pandi kokku ja kaeti nahaga. Seati kokku nii, et näis, nagu magaks elav põhjapõder, pea jalgade juurde painutatud (Tsharnoluski 1966: 305-306). Käesolevas muinasloos lubati üksnes esiemal põhjapõdra pea koos ajuga ära süüa, muidu oli see naisterahvastel teatavasti tabu (nt Itkonen 1946: 269 soome viljastumiseas olevate lapi naiste kohta; lapsed ja eided võisid kõiki kehaosi ja elundeid süüa).

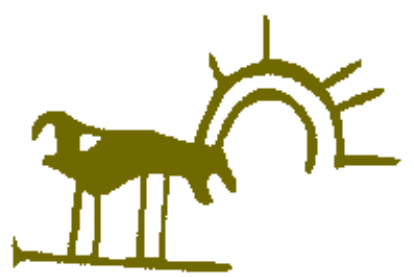

Voolavat vett pidasid saamid maagiliseks, universaalseks puhastusvahendiks. Nende usundis kandis ta nahad uute põhjapõdraalgete sünnipaika. Edastame V. Tsharnoluski (1965: 78) vahendusel teejuht Jestrati-taadi jutu:

Põhjapõdranahad tõusevad taevasse, meie keeli jula (*24). Meandash ise käskis tapetud põhjapõtrade nahad voolavasse vette heita. Ta käskis nad jätta vete hooleks.

Vooluvett pidi ujuvad nahad merre või kuhugi sinna kanti, kus neile on määratud, hiljem aga meie juurde, Suveneemele tagasi. Merest ja päikese juurest tulevad nad meie juurde. Nüüd on nad Meandash-põõrre'd. Meandash juhib neid. Ta juba on kord selline..."

Jutust selgub, et nahad ujuvad saami kujutelmades kuhugi kaugele, kust nad tõusevad taevase päikesejumala Meandash-põõrre juurde, keda käsitleme lähemalt järgmises peatükis. 
Teine pahategu on lisatud didaktilise tagamõttega lisatud või on see V. Tsharnoluski liidendus. Jätkame lugu tema sõnadega:

Elu aga veeres edasi. Mees hakkas edukat jahti pidama.

Eluke veeres edasi, ema aga sõitleb tütart, miks ta ei kuivata asemenahku päikese käes, vaid heidab need vooluvette. Tütar võttis ema sõna kuulda, pani naha päikese kätte kuivama, ise aga läks kotta. Päike veeres looja. Naine väljus kojast, et tuua nahk tuppa, kuid seda polnudki enam!

Keegi ei tea, kuhu kadus see nahk!

Neljateistkümnes jutt (kokkuvõtet vt "Mäetagused", $\underline{\text { nr 6, }}$ 1k 28)

Selle jutu kirjapanek on usaldusväärne, lugu napisõnaline, kuid kõiki motiive sisaldav. Põhjapõdra naha ärapõletamisele järgnes looma- ja inimeseriigi lahknemine. Anname jutuotsa V. SienkiewiczGudkova ja K. Kondi vahendusel turjalasele Ustinja Tarunovale:

Tema mees kolis ära koos lastega. Tema mees põgenes metsa ja lapsed ka. Kõik jooksid põhjapõtradeks muutunutena metsa.

Aga nende ema nutab, nutab ja hü̈аb: "Tulge, tulge ema juurde!" Aga lapsed hü̈̈avad:

"Meie ei või tulla sinu juurde tagasi, meid, meid tõmbab mets." Ja tema lapsed läksid metsa.

Nende ema jäi üksi. Nende ema jäi ilma lasteta. Ta jäi nuttes elama oma isaga.

Ka selles loos rõhutatakse metsa (loodude) kutset, mis on inimeste maailma jaoks muutunud sündmuste käigus ületamatuks.

Viieteistkümnes jutt (kokkuvõtet vt "Mäetagused", 싸 6, lk 28 jj)

See Turja lugu on üpris sarnane XII jutuga. Ka asjaomases muinasloos abiellus põhjapõdra naine pärast pahategu ja põhjapõdra kodunt pagemist sureliku mehega ja elu ei läinud esialgu nii nagu vaja. Põhjapõdrast mees õpetas unes naisele, kuidas toimida, et elu muutuks õnnelikuks: põhjapõder tuleb tappa, tema naha peal magada ning tema pea koos ajuga ära süüa.

Käesolevas loos rõhutatakse, et vana põhjapõdra elu oleks mõttetu (hambad on lahti, mis tähendab surmale määratust, sest ta ei saa enam süüa), kui teda ei kasutataks rituaalsel otstarbel. Põhjapõder käskis naisel panna pea asemenaha kõrvade kohale, sest põhjapõdra hing asus just kõrvades (vt XXII jutt).

Eriti huvipakkuv detail on põhjapõdra silmade söömine, mis seondub maaema ja viljakuse kultusega. Arktika rahvad omistasid ulukite, sh põhjapõtrade silmadele olulist tähtsust (Simtshenko 1976: 236 jj). Nganassaani uskumustes ei tohtinud metsiku põhjapõdra pead minema visata, vaid sel tuli silmad välja lõigata ja maha matta, st tagastada nad maaemale (Mou-nämõ). Silmi ei eemaldatud koduloomadel (ka saamidel ei laienenud metsiku põhjapõdraga seonduvad tabud kodustatule, vt Itkonen 1946: 269). Nganassaani maaema kujutleti põhjapõdrana ning pinnakatet tema karvase nahana. Pimedaksjäämist käsitleti silmade sooviga lahkuda siitilmast maaema juurde. Nganassaanid väitsid inimese ja loomade sündimisel, et "Maaema sünnitas silmad". Sõnadega seime 'silm' ja seimidä tähistasid nad vastavalt mõisteid 'loode' ja 'sündida (silmadest)'. Silmadega seonduvad kujutelmad esinevad ka neenetsitel, eenetsitel, tshuktshidel jt rahvastel. Üks eenetsi 
keelejuht on väitnud, et silmad tuli tapetud loomal seepärast eemaldada, et loom ei näeks enam põgeneda. Ka saamidelt pärineb Tuderuse vahendusel teade (1910), et tapetud põhjapõtra ei tohtinud tuua kotta, silmad peas. J. Simtshenko uurimuse kohaselt pole need uskumused tekkinud konvergentselt, vaid nad on pärandunud tänapäeva saamidele ja teistele tundrarahvastele metsikuid põhjapõtru küttinud tundmata substraathõimult. Peale selle rõhutab ta, et maaema kultus on põhjahõimudel ühenduses kivide, saamidel seega seitade kultusega.

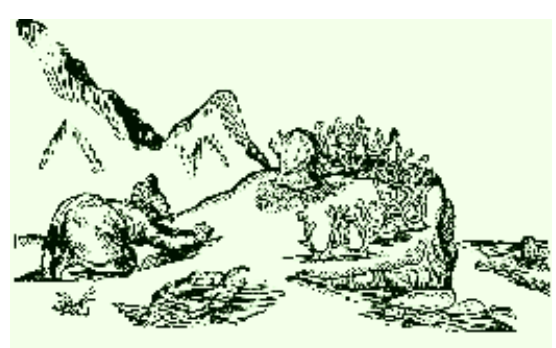

Milliseid oletusi saab teha eespool refereeritust? Silmade söömises võib kajastuda algrituaal, mille sisuks oli viljakuse tagamise otstarbel esimeste põhjapõdraloodete omandamine maaema poolt. Muinassaamide mõttemaailma taastades võib oletada, et söömise teel sisenesid silmad naisesse (vrd millegi söömise seost rasestumisega mitme rahva uskumustes) ning see naine oli tegelikult maaema, mida ju väitis ka jutuvestja Tatjana Danilova (vt "Mäetagused" nr 6, lk 25-26). Põhjapõtrade ja maa seosest on jutustanud ka rootsi saamid, kes ohverdasid põtru toitvale ja neile suguiha andvale maale (Holmberg 1915: 60).

\section{Seitsmeteistkümnes jutt (kokkuvõtet vt "Mäetagused", nr 6)}

Lõpuosas on asjaomane jutt kaheksanda variandi kosjade ja külaskäigu kirjeldamisega võrreldes palju sarnasem. Seitsmeteistkümnendas teisendis puudub vaid ema ja noorima poja vaheline dialoog.

Kaheksateistkümnes jutt (kokkuvõtet vt "Mäetagused", nr 6, 1k 32-33)

Selle teadmata kohast üleskirjutatud jutu ebatäpsustest oli juttu juba eelmistes "Mäetagustes". Lisatagu veel lahknevustest, et 1) kaarna ja hülge lapsed ei tundnud oma vanaisa, kuid põdrapojad hõikasid juba kaugelt, et vanaisa tuleb; 2) põhjapõdrale mehele läinud tütar ei tahtnud, et taat jääks sinna ööseks; 3) kui taat ei kavatsenud lahkuda, hoiatas tütar taati aseme märgamise eest; 4) ema laulis pojale hoiatuslaulu, milles kästi hoida eemale suurest kivist ja künkast, hoida sinnapoole, kust kuuldub sarvede heli ja vasika häält, mille järgi tunneb omaksed ära. Laul lõpeb järgmiste värssidega:

Jookse, jookse, mu poeg!

Kümnendale jõelättele, onnelikule katlale!

Ilmselt peetakse viimasel juhul silmas edukat kütti. Sama toidurikkuse ideed kätkeb ka XII loo laul, mis kõneleb Meandashi seosest täiskatlaga:

Elas kord Meandash

ja katel oli suur.

See kees, ääreni täis.

Täisleek siis täie katla,

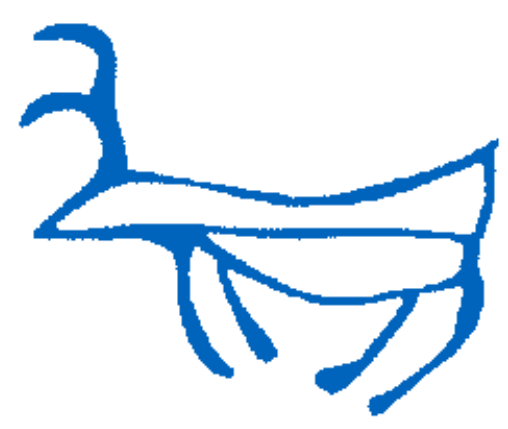

katla põhja vallutas.

Kogu katla ümber lõomas. 
Jutustaja väljendab muinasloo jutustamisel ka oma suhtumist tegelastesse:

Nii tõi vanaisa õnnetust, ent vanaema ei saanudki näha oma lapselapsi. Mul on kahju väikesest piimavasikast, ent veel rohkem kahju vanaemast. Kuid pole viga, teises kohas saame teada, et vanaema on taas lastelaste juures.

Viimane lause näib viitavat, nagu pajataks jutustaja veel teisegi samateemalise loo, millest aga pole paraku midagi teada.

$*$

Kahekümnes jutt (kokkuvõtet vt "Mäetagused", nr 6, lk 33 jj)

See 1887. aastal noteeritud kolta lugu on lahkumismotiivistiku poolest tavaline. Koerinimene hoiatas naist, et ei tohi lubada lastel asemele pissida, kuid ometi see juhtus ja nahad pandi päikese kätte kuivama.

Ema hoiatuses mainitud kardetavad mustad loomad on karud (vt ka I jutt), kellele vastandatakse inimesi, keda ei pea pelgama, sest nende valmistatud nöörpüünised ei tegevat põtradele viga. Selles väljendatakse ideed, et viimased on muutunud paratamatult inimeste püügiobjektiks. Ema hoiatustest nähtub selgesti, et tegu on põhjapõdraga, kes koertele püüniseid seab. Lugu lõpeb sellega, et ämm ja ja tütar hakkasid põhjapõdravasikaid sünnitama.

\section{Kahekümne teine jutt}

"Pro dikihh". V. Tsharnoluski, 1936 < vanaema Fedosja. Aahkkel. Tshurjauri ja Imandra vahel. Avaldatud vene keeles Tsharnoluski 1972: 111-112; Kert 1980: 219-220 (nr 137).

Lahkumine naise juurest. Vanemate kojas elades vihastas mees omaste peale, muutus põhjapõdraks ja otsustas kodunt ära minna. Abikaasa hakkas nutma ja palus, et mees võtaks ta endaga kaasa, kuid see keeldus ja soovitas tal abielluda naabrimehega, kes laseks põdra Pühajärve lähedal maha. Seejärel käskis ta naisel magada tapetud põhjapõdra nahal nii, et ta saaks esimese abikaasa hinge vastu võtta, kuid poole sellest peab ta tagasi andma.

Naise edasine elu. Naine tegigi nõnda, kuidas põhjapõder soovis. Ema nägi põhjapõtru kojast välja jooksmas. Hiljem nähti sealkandis sageli kaht ühesugust sõbralikku sarvast ringi käimas.

Müüdi seletus. Taoline lugu juhtus seeläbi, et mees kinkis armastatud naisele poole oma hingest.

See lugu sarnaneb üldjoontes XII looga, sest mõlemas on juttu teistkordsest abiellumisest surelikuga, põhjapõdra tapmisest ja tema naha peal magamisest. Jutu eripärasuseks on, et: 1) puuduvad algusmotiivid, sh pissimisega seonduv pahategu, 2) naine muutub põhjapõdraks, huvitaval kombel sarvaks ning 3) lool on teistest erinev etioloogiline lõpp (seostamine püsiva armastusega naise ja mehe vahel). Esimene ja viimane iseärasus võivad olla sekundaarsed. Põhjapõdrast abikaasa laulab:

Mine naabrile mehele ja kingi talle minu amb. Mine temaga koos jahile. Minge meie tshiigarile ülevalpool Pühajärve. Saada ta sinna. Seal avaruses söön ma rohtu ja kõnnin vastutuult. Las ta laseb mind maha, tapab mu ja nülib naha. Las kõik me suguvõsa sööb mu 
liha, kuid sina ära mu liha puutu ega söö, kuid võta endale käbedasti mu nahk. Riputa see kuivama. Kui nahk on kuivanud, siis vii ta kotta ja pane kahekorra, karv väljapoole. Kui heidate koos mehega magama, siis sina mässi end mu naha sisse. Heida mehe poole seljaga, et ta ei saaks sind emmata. Ühe nahapoole peale heida ise, teine pool aga mässi keha ümber. Oma pea pane sa naha kõrvade peale ning kannad aseta sabale. Pane kõrv kõrva vastu. Mu hing elab naha kõrvades. Võta mu hing, kuid pool sellest anna tagasi. Ära siis unusta! Kui ärkad, muutud kohe põhjapõdraks...

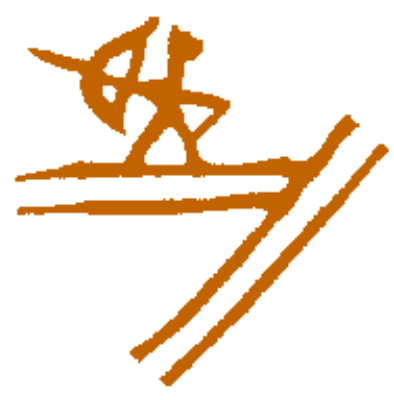

Nagu XII loos tuleb siingi põhjapõtra ambuda pühapaigas, millele osutab kohanimi Pühajärv. Abiellumine naabrimehega on tarvilik ainuüksi selleks, et mees tapaks ja nüliks põhjapõdra, kuna naisele polnud jahilkäik lubatud. Naha töötlemine jääb aga naise teha.

Järgneb esimese ohvripõdra rituaal, mille kirjeldusest niipalju, et naine ei tohtinud põdraliha puudutadagi. V. Tsharnoluski poolt turjalastelt kogutud andmetest saame teada, et jahihooaja alguses tabatud esimese looma ohverdamisriitusel osalesid ainult lähedased meessugulased (poeg, isa või lell) ning naisterahvad ei võinud liha puudutada. Samuti polnud ohvriliha määratud naisterahvaste jaoks, "vaid küti, tema isa, poegade ja meessoost lastelaste heaks, samuti ka küti enda suguvõime säilitamiseks. Seega oli see meeste toodud ohver, mis pidi kindlustama jahiõnne. I. Matrjohhini sõnul tähendas see, et ohvripõder söödi meeste poolt Meandashi nimel, see läks Meandashi heaks. See oli Meandashiga ühinemise rituaal." (Tsharnoluski 1966: 305). Põhjapõder ohverdati Meandash-anntuchch'ile, st Meandash-andjale (samas: 302). Ilmselt on ka vaadeldavas muinasloos tegu äsjakirjeldatud ürgrituaaliga, mida korrati kuni käesoleva aastasajani välja.

Tapetud abikaasa naha peal magamise motiiv on meile eelmistest lugudest juba tuttav, kuid käesolevas loos leidub huvitavaid täpsustusi. Loomaks moondumisel ei piisa naha peal magamisest, nagu seda eelmiste juttude järgi võiks arvata, vaid siin on oma kindel kord, nimelt tuleb heita naha peale nii, et pea satuks naha peaosale, täpsemini, selle kõrvadele. Üldiselt meenutab see Audne lugu, kuid on vastupidise eesmärgiga: seal oleks karuks moondunud naine saanud täielikult tagasi inimkuju, kui ta kõik kehaosad oleksid mahtunud naha peale (vt II ekskurss). Ilmselt pole juhuslik ka maining, et karv peab jääma väljapoole. Karvasus on ju viljakuse sümboleid. Hinge jagamise kohta saame järgmise pildi:

Ta tegi kõik nõnda, nagu käskis metsikust põhjapõdrast mees: heitis jalakannad saba poole, käed ja labajalad naha jalgade poole. Asetas pea

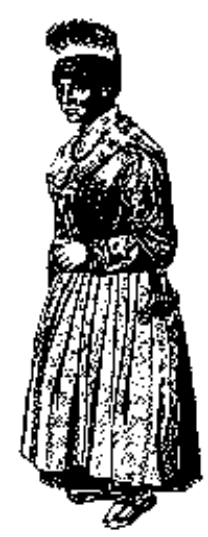
nõnda, et ta kõrvad sattusid naha kõrvade vastu. Ühe kõrvaga võttis ta vastu hinge, teise kõrva kaudu tagastas teise poole. Ta uinus sügavasti. Ning äkki tõusis ta, viskus üles... Teised ainult kuulsid kõike, kuid ema ka nägi, nagu oleksid põhjapõdrad jooksnud kojast välja.

\section{Kokkuvõtvalt lahkumislugude kohta}

Meandashi-lugudes esineb kaht laadi põgenemist: ema ja naise juurest. Teist lahkumistüüpi on talletatud ühtekokku 13 variandis, sh Imandra äärest, Aahkkelist ja koltadelt, igaühelt 2 teisendit ning 
kildinitelt 4 ja turjalastelt kolm teisendit. Seega oli põhjapõdra põgenemise motiiv tuntud kogu Koolas. Peale selle teatakse veel kolme ema juurest põgenemise lugu, neist kaht koltadelt ja üht turjalastelt. Need pakuvad huvi ema reaktsiooni tõttu.

Mõlemas Imandra kandist noteeritud loos on lahkumise kirjeldus ühesugune, kuid ema reaktsioon on üpris erinev. Mõlemad on ühenduses abiellumise esimese alltüübiga. Aahkkeli (samuti läänepoolsed) lood pole omavahel võrreldavad. Teine neist on sarnane Turjast pärineva XII ja XV jutuga, milles kõneldakse naise teisest abiellumisest sureliku mehega. Erinevalt Imandra lugudest on Aahkkeli lool (VIII) seos abiellumislugude teise alltüübiga; ema reaktsioonis on I jutuga ühine vaid rinnapakkumine, muidu see erineb.

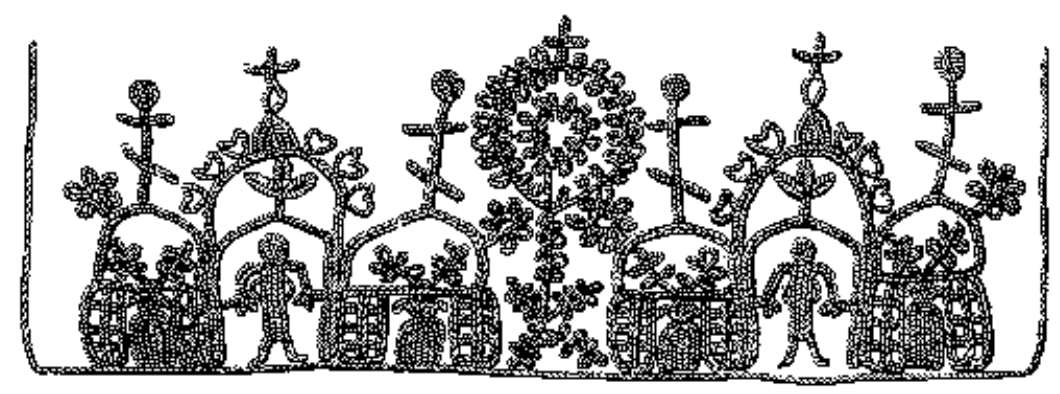

Lahkumise motiiv võib liituda kõigi kolme abiellumistüübiga (tabel 8). Tõsi küll, pooltel juhtudel (3 teisendit) on tegu esimese põgenemisega. Neist kahes variandis pole ema reaktsiooni põhjal võimalik diferentseerida, kumma põgenemise juurde ta kuulub. Ühes kolta loos (III teisend) tahtis ema täiskasvanud pojale tissi anda, mis pole aga usutav, sest teistes lugudes toimitakse nii rinnalastega.

Pahateo puhul huvitavad järgmised küsimused: 1) milles pahategu seisnes (missugust tabu rikuti)?, 2) kes märgas aseme? 3) kes oli süüdlane? (tabel 8).

\begin{tabular}{|c|c|c|c|c|}
\hline $\begin{array}{l}\text { Jutu number ja } \\
\text { päritolu }\end{array}$ & $\begin{array}{l}\text { Abiellumis- } \\
\text { tüüp }\end{array}$ & Pissija & Pahategija & Pahandus \\
\hline 1. Imandra & $\mathrm{I}$ & laps & - & paha hais \\
\hline 3. Kildin & - & -"- & naine & riputas naha üles \\
\hline 6. Imatra & I & -"- & - & paha hais \\
\hline 8. Aahkkel & II & -"- & ämm & $\begin{array}{l}\text { riputas naha ukse } \\
\text { ette }\end{array}$ \\
\hline 9. Kildin & II & äi & naine & $\begin{array}{l}\text { riputas naha } \\
\text { tagauksele }\end{array}$ \\
\hline 10. -"- & II & -"- & ämm & $\begin{array}{l}\text { kuivatas nahka } \\
\text { teerajal }\end{array}$ \\
\hline 12. Turja & II & laps & $\begin{array}{l}\text { ämm -/ } \\
\text { naine }\end{array}$ & $\begin{array}{l}\text { kuivatas nahka } \\
\text { päikese käes }\end{array}$ \\
\hline 14. -"- & II & - & naine & põletas mehe naha \\
\hline 15. -"- & II & - & ämm & riputas naha \\
\hline
\end{tabular}




\begin{tabular}{|l|l||l||l||l||}
\hline \multicolumn{1}{|l|}{} & & & & kuivama \\
\hline 18. Teadmata & II & taat & naine & $\begin{array}{l}\text { kuivatas nahka koja } \\
\text { juures }\end{array}$ \\
\hline 19. Kildin & II & lapsed & ämm & riputas naha uksele \\
\hline 20. Kolta & III & laps & - & paha hais \\
\hline 22. Aahkkel & - & - & omaksed & ? \\
\hline
\end{tabular}

Tabel 8. Abiellumistüüp ja pahategu.

Eripärasest Aahkkeli loost (XXII) pole selge, mille peale põhjapõder vihastas. XIV jutus on tegu abikaasa naha põletamisega; see on laenuline motiiv (vt "Mäetagused", nr 6, lk 28). Kahes Imandra kandi ja ühes kolta teisendis kõneldakse ainult lapse asemenaha märgamisest. Ülejäänud 8 loos $(61,5 \%)$ on rikutud täispissitud nahaga ümberkäimise reeglit: seda ei visatud vette, vaid pandi kuskile päikese kätte kuivama. Kahes Kildini loos (IX ja X) ja ühes teadmata päritolu teisendis (XVIII) on öösel naha täis pissinud äi (kokku 23\%), 8 juhul $(61,5 \%)$ aga, nagu see on mõistetav, laps. XVIII variant on tuntud mitme seiga unustamise poolest (vt "Mäetagused", nr 7). Kas ka ülejäänud juhtudel on tegemist unustamisega, ei julge väita: võib-olla polnud täispissija isik oluline, vaid tähtsam oli taburikkumise ja sellele järgneva kirjeldamine.

Käsitleme kuueteistkümne teisendi põhjal (tabel 9)detailsemalt ka ema reaktsiooni. Laste lahkumise eel ema: 1) pakkus neile tissi, 2) hoiatas neid ohtude (inimene, loomad) eest, 3) needis poja ja/või 4) jagas neile eluõpetusi (tabel 9).

\begin{tabular}{|l|l|l|l|l|l|l||}
\hline $\begin{array}{l}\text { Variandi } \\
\text { number ja } \\
\text { päritolu }\end{array}$ & Imetamine & $\begin{array}{l}\text { Hoiatus } \\
\text { inimese } \\
\text { eest }\end{array}$ & $\begin{array}{l}\text { Hoiatus } \\
\text { looma } \\
\text { eest }\end{array}$ & $\begin{array}{l}\text { Poja } \\
\text { needmine }\end{array}$ & $\begin{array}{l}\text { Soovitused } \\
\text { saada } \\
\text { saakloomaks }\end{array}$ \\
\hline 1. Imandra & + & + & + & - & - \\
\hline 2. Kolta & + & - & - & - & - \\
\hline 3. Kildin & + & + & - & - & - \\
\hline 4. Turja & - & - & - & + & - \\
\hline 5. Kolta & - & + & - & - & - \\
\hline 6. Imandra & - & + & - & - & + \\
\hline 8. Aahkkel & + & - & - & - & - \\
\hline 9. Kildin & + & + & - & - & - \\
\hline 10. -"- & + & + & - & - & - & - \\
\hline 12. Turja & + & - & - & - & - & - \\
\hline 14. -"- & - & - & - & - & - \\
\hline 15. -"- & + & - & - & - & - \\
\hline
\end{tabular}




\begin{tabular}{|c|c|c|c|c|c|}
\hline $\begin{array}{l}18 . \\
\text { Teadmata }\end{array}$ & + & + & - & - & - \\
\hline 19. Kildin & - & - & - & - & - \\
\hline 20. Kolta & - & - & + & - & - \\
\hline 22. Aahkkel & - & - & - & - & - \\
\hline Kokku & 9 & 7 & 2 & 1 & 2 \\
\hline
\end{tabular}

Tabel 9. Ema reaktsioon.

9 juhul (56,2\%) andis ema lastele rinda ja 7 juhul (43,8\%) hoiatas neid inimese eest. Ema teised reageerimisviisid jäävad üksikuteks. Näiteks ühes Imandra (VI variant) ja Turja (XII) loos soovitas ta põhjapõdrapojal olla inimesele saagiks. Ühel juhul (I teisend) muutus ema põhjapõtrade haldjaks. Öeldust selgub, et peamiseks jääb noore põhjapõdra hoiatamine halva inimese eest. Selle tagajärjeks võiks olla populatsiooni hävimine.

Omapärased on kaks Turja, üks Aahkkeli ja üks Kildini variant, milles räägitakse lesestunud põhjapõdranaise abiellumisest sureliku mehega. Kokkuvõtteks võib nentida, et põgenemise motiivis esineb varianditi pisikesi lahknevusi, kuid see kajastab kujukalt ühe muistse tabu rikkumist ja sellega seonduvat, samuti aitab ta vastata etioloogilistele küsimustele: 1) miks põhjapõdrad elavad inimestest lahus? (VIII variant), 2) kuidas sai alguse põhjapõtrade küttimine? (IV jutt) ning 3) miks põhjapõder on kartlik? (V lugu).

\section{Täiendav kirjandus}

Rõbakov, B. A. 1994. Jazõtshestvo drevnihh slavjan. Izdanije 2-e. Moskva.

Simtshenko, J. B. 1976. Kultura ohhotnikov na olenei Severnoi Jevrazii: etnografitsheskaja rekonstruktsija. Moskva. 


\section{Illustratsioonid}

Joonis 29. Koola saam talverõivastuses. N. Haruzini (1890) järgi.

Joonis 30. Müütilise põhjapõdra kujutis saami shamaanitrummil.

Joonis 31. Kivist seita kummardamas. J. Schefferuse (1674) järgi.

Joonis 32. Elujoonega põhjapõdra kujutis saami shamaanitrummil.

Joonis 33. Müütiline kütt vibu ja noolega saami shamaanitrummil.

Joonis 34. Koola saamitar suvises rõivastuses. N. Haruzini (1890) järgi.

Joonis 35. Naised ja põdrad kolmelöövilises kirikus. Tikand Tveri kubermangust (1880-ndad aastad). Rõbakov 1994: 485 järgi, vt ka 480). Kompositsiooni sakraalsuses pole kahtlust.

\section{Kommentaarid}

$23 \mathrm{~V}$. Tsharnoluski kasutas siinkohal sõnaühendit taevainimene, mis oli ilmne väärtõlgendus (vrd saami all'm - taevas, ollm - tavaline, ilmne, ollm-olmannts' - tavaline inimene).

24 Siinkirjutaja ei leidnud seda sõna sõnaraamatuist. 